Acknowledgements: This study was funded by Novartis Pharma AG. The authors thank Richard Karpowicz, PhD, of Health Interactions, Inc, for providing medical writing support/editorial support, which was funded by Novartis Pharmaceuticals Corporation, East Hanover, NJ, in accordance with Good Publication Practice (GPP3) guidelines (http://www.ismpp.org/gpp3).

Disclosure of Interests: Gurjit S. Kaeley Consultant of: Novartis Pharmaceuticals Corporation, Georg Schett Speakers bureau: AbbVie, Bristol Myers Squibb, Celgene, Janssen, Eli Lilly, Novartis, and Pfizer, Consultant of: AbbVie, Bristo Myers Squibb, Celgene, Janssen, Eli Lilly, Novartis, and UCB, Grant/research support from: Bristol Myers Squibb, Celgene, GSK, Eli Lilly, and Novartis, Philip G Conaghan Consultant of: or Speakers bureau: AbbVie, AstraZeneca, Bristol Myers Squibb, Eli Lilly, EMD Serono, Flexion Therapeutics, Galapagos, Gilead, Novartis, and Pfizer, Grant/research support from: UK National Institute for Health Research (NIHR) Leeds Biomedical Research Centre, Dennis McGonagle Speakers bureau: Roche, Sobi, and Novartis, Grant/research support from Novartis, Frank Behrens Consultant of: Pfizer, AbbVie, Sanofi, Lilly, Novartis, Genzyme, Boehringer, Janssen, Merck Sharp \& Dohme, Celgene, Roche, and Chugai, Grant/research support from: Pfizer, Janssen, Chugai, Celgene, and Roche, and has received investigator fees from Eli Lilly, Philippe Goupille Grant/ research support from: and/or Consultant of/Speakers bureau: AbbVie, Amgen Biogen, Bristol Myers Squibb, Celgene, Chugai, Janssen, Lilly, Medac, Merck Sharp \& Dohme, Nordic Pharma, Novartis, Pfizer, Sanofi, and UCB, Corine Gaillez Employee of: Novartis Pharma AG, Bhumik Parikh Employee of: Novartis Pharmaceuticals Corporation, Xiangyi Meng Employee of: Novartis Pharmaceuticals Corporation, Catherine Bakewell Consultant of: and/or Speakers bureau: AbbVie, Novartis, Pfizer, Janssen, UCB, and Sanofi Genzyme/Regeneron DOI: 10.1136/annrheumdis-2021-eular.463

\section{POS0195 GUSELKUMAB TREATMENT MODULATES CORE PSORIATIC ARTHRITIS GENE EXPRESSION IN TWO PHASE 3 CLINICAL TRIALS (DISCOVER-1 AND -2)}

S. Siebert ${ }^{1}$, K. Sweet ${ }^{2}$, C. T. Ritchlin ${ }^{3}$, E. C. $\mathrm{Hsia}^{2,4}$, A. Kollmeier ${ }^{5}$, X. L. Xu ${ }^{5}$, Q. Song ${ }^{2}$, M. Miron ${ }^{2} .{ }^{1}$ University of Glasgow, Institute of Infection, Immunity and Inflammation, Glasgow, United Kingdom; ' Janssen Research \& Development, LLC, Immunology, Spring House, United States of America; ${ }^{3}$ University of Rochester Medical Center, Department of Medicine, Allergy/Immunology and Rheumatology (SMD), Rochester, United States of America; ${ }^{4}$ University of Pennsylvania Medical Center, Rheumatology, Philadelphia, United States of America; ${ }^{5}$ Janssen Research \& Development, LLC, Immunology, San Diego, United States of America

Background: Guselkumab (GUS), an interleukin-23 p19-subunit monoclonal antibody, demonstrated efficacy compared with placebo (PBO) in reducing signs and symptoms of psoriatic arthritis (PsA) in the phase 3 DISCOVER-1 \& 2 studies. ${ }^{1,2}$

Objectives: To evaluate gene expression in the blood of PsA patients (pts) in the DISCOVER-1 \& -2 studies and the impact of GUS on the expression of these genes.

Methods: Pts were treated with GUS $100 \mathrm{mg}$ every 4 weeks (Q4W); GUS $100 \mathrm{mg}$ at W0, W4, then Q8W; or matching PBO. Whole transcriptome profiling by RNA-sequencing was performed using the Novaseq platform on blood samples obtained from a subset of 673 pts with PsA at baseline across the 2 DISCOVER studies, as well as from 21 demographically (age, sex, and ethnicity) matched healthy controls procured independently of the clinical program. A subgroup ( $\mathrm{N}=227$ ) also had serial blood samples (WO/W4/W24) evaluated; the subgroup pts were selected based on having baseline characteristics (demographics, disease activity, medication use) representative of the overall cross-study PsA population. Significance of differentially expressed genes (DEGs) between PsA and healthy controls was defined by a false discovery rate (FDR) $<0.05$ based on a log-linear model using edgeR. Top genes were defined by significance and $\| \operatorname{logFCl}>1$. For cell type analysis, genes that changed with GUS treatment were tested for enrichment using Cibersort. Gene enrichment scores were calculated using Gene Set Variation Analysis (GSVA).

Results: To define disease genes, we compared genes at baseline in pts with active PsA vs. healthy control whole blood transcriptomes and detected 355 upregulated and 314 downregulated (top genes shown in Table 1), defined here as core disease genes. Upregulated genes were largely related to neutrophils, monocytes, macrophages, and extracellular matrix, whereas downregulated genes were related to $T$ cells. The upregulated disease genes were significantly decreased and the downregulated disease genes were significantly increased by GUS treatment vs. PBO at W4 and W24 (Fig 1). Upon stratification by Psoriasis Area and Severity Index 75\% response and American College of Rheumatology $20 \%$ response, changes in core disease gene expression from Wo were statistically significant among responders, but not in non-responders, at W4 and W24 (data not shown). We then performed the second differential expression analysis comparing baseline to W4 and W24 for both PBO and GUS treatment arms to define genes that change with treatment arm over time. At W4 and W24 we found many DEGs from baseline with GUS treatment and none with PBO. These included genes related to B-, T-, NK-, and plasma cells (increased by GUS) and neutrophils, monocytes, eosinophils, and macrophages (decreased by GUS), suggestive of a partial normalization of immune cell composition in whole blood. Conclusion: Using whole transcriptome profiling, we detected DEGs in blood samples obtained from PsA pts vs. healthy controls, suggesting a dysregulation of immune cell profiles in PsA. The majority of these disease-associated genes were modulated by GUS, with directionality toward a normalization of whole blood transcriptomic signatures.

\section{REFERENCES:}

[1] Deodhar A et al. Lancet. 2020;395:1115

[2] Mease $\mathrm{P}$ et al. Lancet. 2020;395:1126.

Table 1. Top DEGs derived from PsA vs. healthy whole blood transcriptomes.

\begin{tabular}{llllllll}
\hline \multicolumn{2}{l}{ Upregulated in PSA } & \multicolumn{7}{l}{ Downregulated in PSA } \\
\hline Gene & logFC & logCPM & FDR & Gene & logFC & logCPM & FDR \\
\hline ADGRG7 & $\mathbf{5 . 9 2}$ & -0.90 & 0.02101 & AK8 & -1.36 & -1.06 & $1.61 \mathrm{E}-07$ \\
ADAMTS2 & $\mathbf{4 . 0 6}$ & 0.82 & 0.006466 & FTCD & -1.48 & -1.74 & $1.67 \mathrm{E}-05$ \\
PGF & $\mathbf{3 . 2 1}$ & -0.68 & 0.006466 & GPR15 & -1.54 & 1.81 & $1.67 \mathrm{E}-05$ \\
PCSK9 & $\mathbf{3 . 2 1}$ & -2.96 & 0.023872 & CHRM3 & -1.54 & -2.62 & $9.6 \mathrm{E}-08$ \\
OLAH & $\mathbf{2 . 7 6}$ & 0.75 & 0.004539 & RFPL4AL1 & -1.69 & -3.34 & 0.009738 \\
MAOA & $\mathbf{2 . 5 5}$ & -0.26 & 0.005463 & SPACA3 & -1.85 & -3.23 & 0.000216 \\
SLC2A14 & $\mathbf{2 . 3 0}$ & 0.59 & 0.022594 & VANGL2 & -1.95 & -1.79 & $9.6 \mathrm{E}-08$ \\
MMP1 & $\mathbf{2 . 2 5}$ & -1.16 & 0.004745 & RFPL4A & -2.04 & -1.28 & 0.004539 \\
DAAM2 & $\mathbf{2 . 1 2}$ & 4.31 & 0.024628 & GLYATL2 & -2.77 & -2.78 & $1.93 \mathrm{E}-15$ \\
& & & & BCAR1 & -3.13 & -2.58 & $6.24 \mathrm{E}-26$
\end{tabular}

Bold indicates positive change. $\mathrm{CPM}=$ counts per million.

Disclosure of Interests: Stefan Siebert Consultant of: AbbVie, Janssen, Novartis, UCB, Grant/research support from: AbbVie, Amgen (previously Celgene) Bristol Myers Squibb, Boehringer Ingelheim, GSK, Janssen, Novartis, UCB, Kristen Sweet Shareholder of: Johnson \& Johnson, Employee of: Janssen Research \& Development LLC, Christopher T. Ritchlin Consultant of: AbbVie, Amgen Gilead, Janssen, Eli Lilly, Novartis, Pfizer, and UCB, Grant/research support from: AbbVie, Amgen, and UCB, Elizabeth C Hsia Shareholder of: Johnson \& Johnson, Employee of: Janssen Research \& Development LLC, Alexa Kollmeier Shareholder of: Johnson \& Johnson, Employee of: Janssen Research \& Development LLC, Xie L Xu Shareholder of: Johnson \& Johnson, Employee of: Janssen Research \& Development LLC, Qingxuan Song Shareholder of: Johnson \& Johnson, Employee of: Janssen Research \& Development LLC, Michelle Miron Shareholder of: Johnson \& Johnson, Employee of: Janssen Research \& Development LLC

Figure. Change from baseline in median GSVA scores for upregulated and downregulated genes in PSA for GUS and PBO treatment arms from DISCOVER-1 and 2.

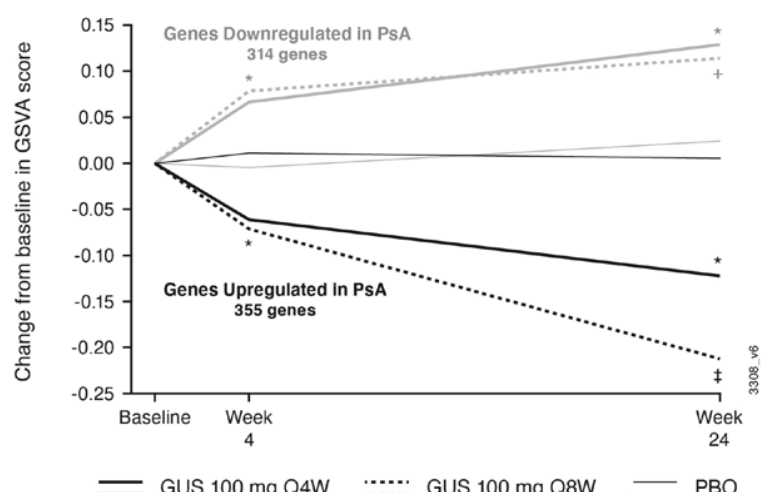

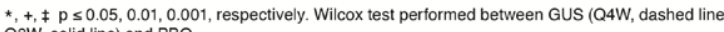
Q8W, solid line) and PBO.

DOI: 10.1136/annrheumdis-2021-eular.479

\section{POS0196 UPADACITINIB IN PATIENTS WITH PSORIATIC ARTHRITIS REFRACTORY TO BIOLOGIC DISEASE- MODIFYING ANTIRHEUMATIC DRUGS: 56-WEEK DATA FROM THE PHASE 3 SELECT-PSA 2 STUDY}

P. J. Mease ${ }^{1}$, A. Lertratanakul ${ }^{2}$, K. Papp ${ }^{3}$, F. Van den Bosch ${ }^{4}$, S. Tsuji ${ }^{5}$, E. Dokoupilova ${ }^{6}$, M. Keiserman ${ }^{7}$, X. Bu², L. Chen ${ }^{2}$, R. Mccaskill ${ }^{2}$, P. Zueger ${ }^{2}$ E. Mcdearmon-Blondell ${ }^{2}$, A. Pangan ${ }^{2}$, W. Tillett ${ }^{8}{ }^{1}$ Swedish Medical Center/ Providence St. Joseph Health and University of Washington, Rheumatology, 